\title{
A Comparative study of satisfaction of consumers while using services of India Post and Private Courier Firms
}

\author{
M.Devika,M.Com.M.Phil. ${ }^{1}$, Dr.V.Renuga,M.Com, M.Phil.Ph.D ${ }^{2}$ \\ ${ }^{I}$ Assistant Prof. of commerce, A.D.M.College for Women,(Aut.) Nagapattinam. \\ ${ }^{2}$ Associate prof. in commerce, A.D.M.College for Women,(Aut.) Nagapattinam.
}

\section{Introduction}

In an era of globalization, the role of the post office and as well as the services it provides has changed significantly. Today, postal services consist of pick-up, transport and delivery services of letters and printed matter (newspapers, journals, periodicals, brochures, leaflets, etc.); parcels for domestic or foreign destinations; post office counter services rendered at counters (sales of stamps, etc); and other postal services such as mailbox rental. The universal postal system is not only used to send and receive letters and parcels, but is now being used to send bank documents, pay utility bills, and deliver goods ordered through the Internet in addition to financial services.

The industry is deeply engaged in the supply chains that have become an integral part of consumer and industrial product manufacturing and marketing. Consumers benefit not only from speed of delivery, but also from lower costs as a result of efficiencies of operation. Innovations such as overnight deliveries and timedefinite deliveries have spurred global competition both by private carriers and by traditional national postal administrations. Competitive benchmarking is a Continuous process of comparing a firm's practices and performance measures with that of its most successful competitors.

\section{Postal Industry}

The Postal service forms part of the daily life of people all over the world. Even in the digital and electronic age the Post remains for millions of people, the most accessible means of communication and message delivery available. Posts are part of a region's overhead capital and networks of transportation. Settlements and communications mediate exchange of goods, information and money between firms and consumers. In addition, they support inter-firm communications and social communication.

\section{Main Services of Postal Industry}

Although there are other peripheral undertakings, the Postal Sector concentrates its efforts in three main areas; Letter mail services, which operate under fastest possible speed in the most secure manner possible, effectively making the world a single territory for the transfer of letter mail items, then there is the Parcels market, which also recently came under treaty obligation as a reserved service, and then there is the Financial services component.

Premium Products are Speed post, Express Parcel, Media Post Greeting Post Logistics Post;

Mail Products are Letters, Inland Letter Card, Post Card, Book Packet, registered Newspaper, Blind Literature Packet, Parcel, Registration, Insurance, Value Payable Post.

\section{Letter Mail}

The global communications market - telephone, fax, electronic mail, interactive communications and other forms of electronic communications - is growing at a much faster pace than the Postal market. This trend, coupled with growing competition from other service providers, will continue tmean a gradual loss of overall market share for the Posts, even if they are showing real growth in physical mail volumes. A downturn in quantities of mail may, however, be offset by still-untapped growth potential, especially for advertising, or direct mail.

\section{Parcels}

The Parcel sector continues to evolve in a very competitive environment. Posts the world over have seen their domestic and international Parcel volumes grow since the beginning of 2000, in particular, thanks to quality-of-service improvements and e-commerce developments. Nevertheless, private operators maintain a firm grip on this market. Indeed, Posts retain only a 32\% share of the domestic parcels market and a $22 \%$ share of the international one. Since parcel sizes and weights have become for the most part regularized, volumes are increasing. 
Outbound flows either plateau at a low volume or continue to decrease. However, there is one country that has shown a tremendous surge in outgoing parcels within the last nine months. This country through various development agencies have encouraged exports by small and medium size entrepreneurs, who find the rates and speed of the Post Office ideal for their businesses. This is a major opportunity for regional post, and should be explored by all.

\section{Postal Financial Services}

Remittances and third-party agency services offered by Posts on behalf of private and public enterprises contribute greatly to the economic and social development of countries. To respond to growing demand for the expansion of Postal Financial Services from users such as migrant workers and various international institutions, Governments and Civil society, the Indian Posts has stepped up its promotion of financial services and is working to create a worldwide electronic fund transfer network based on international cooperation. This too is a highly competitive and, for the most part, unregulated area of commercial activity.

Although kept under the scrutiny of national anti-money laundering entities, there is no regional attempt at regulating this segment of the business. Western Union join the Post in providing the remittance service in the region. These private agencies are found in every place in the region. There are three hundred and seventy-eight outlets for Western Union, seven of these counters are in Post Offices. The demand for quick, safe, secure and affordable transfer of remittances continues to grow. In some member states, provisions are being made for larger amounts to be allowed to customers. This is countered by the real fear of money laundering.

\section{Post Office Saving Schemes are}

Savings Account ,Recurring Deposit (RD) Account, Time Deposit (TD) Account, Monthly Income Scheme (MIS) Account, Public Provident Fund (PPF) Account, National Savings Certificates (NSC), Senior Citizen Savings Scheme (SCSS) Account, Negative List,

Sukanya Samriddhi Accounts, Kisan Vikas Patra (KVP)

\section{Money Remittance Services are}

Money Order (MO), Instant Money Order (IMO), Electronic Clearance Service (ECS) IFS Money Order, Mobile Money Transfer

Mutual Funds, Investment steps, List of Post Offices distributing Mutual Funds and Bonds, Forex Services, Goals and objectives, Products \& Services

Postal Life Insurance(PLI), Rural Postal Life Insurance (RPLI)

Login to - http://www.postallifeinsurance.gov.in *Jansuraksha Scheme

Postal and Courier infrastructure services provide essential two-way links that bring buyers and sellers together, forge markets, build relationships, act as a distribution channel and collector of revenue, facilitate and complete transactions and fulfill demand or orders. Courier is a person or company employed to deliver messages, and mail. Couriers are distinguished from ordinary mail services by features such as speed, security, tracking, signature, specialization and individualization of services, and committed delivery times, which are optional for most everyday mail services. As a premium service, couriers are usually more expensive than usual mail services, and their use is typically restricted to packages where one or more of these features are considered important enough to warrant the cost. Different courier services operate on all scales, from within specific towns or cities, to regional, national and global services. Present and future anticipated opportunities for the development of trade in Postal and Courier services, based on demand both Regional and Global level.

\section{Courier and Express Mail Services}

The Courier and Express Service are operationally distinct from the traditional postal services, geared to a higher level of speed and reliability. The essence of Courier services lie in the seamless and efficient coordination of collection, transportation and the delivery of items. They have explored and developed a niche for urgent exchange of physical communications, making it into a billion of rupees in global business. Postal and Courier services can be categorized as communications and logistic service.

\section{International Couriers}

The proliferation of international Couriers in the region testifies to the strong developmental potential of this service industry. Every country has international Courier offices. Established Courier services such as FedEx and DHL and UPS dominate the regional market in both in-bound and out-bound document and package/parcel services. There are thirty-three (33) DHL offices, one hundred and six (106) FEDEX, and thirty- 
five (35) UPS offices at the last count and these are growing rapidly. These services operate under a legal framework that supports commercial activity in an unregulated environment

The international Couriers are supported by the organizational and technological expertise of their multinational parent companies. They offer value added services and have the ability to readily respond to market forces with aggressive promotional campaigns and pricing and discounting techniques. FedEx, DHL \& UPS provide customers with an array of document and package/parcel services through their global network systems. They have gained competitive advantage by including customs brokerage services in their offerings. These companies continue to reinforce their strengths through alliances and mergers. They strategise to gain consultative status in international organizations such as the WTO World Customs organizations and the Universal Postal Union, in order to legitimize their activities, and lobby for their interests.

\section{Regional Couriers}

Almost every regional air carrier has tried to cash in on the lucrative Express mail business. The brand is associated with the airline, with names such as Jet Pack, LIAT Quick Pak and Star Pac. Priority is given to their packages. Post Offices must depend on these carriers to take their mail.

The demands for cheaper goods and more professional services will continue to fuel the growth of the packages market, any down turn in this business will be seasonal or cyclical. It is expected that when there is general economic down turn the Industry will contract, but will expand during economic upturns.

\section{Postal and Courier Services}

The following are the Functions concerned with postal and courier services

- Processing of licence applications for postal and courier services operators;

- Ensure that postal and courier operators provide sufficient, reliable and efficient services ;

- Manage postal codes and the national address system;

- In collaboration with the tariffs and competition division, advise the Authority on appropriate rates and charges of basic postal service;

- In collaboration with the tariffs and competition division, promote competition among postal and courier service providers;

- Monitor compliance with performance standards and codes of conduct in respect of postal and courier services;

- Act as arbitrator in conflicts involving operators or between operators and customers within the sector;

- Provide advice to the Authority on postal matters;

- Administer implementation of the National Postal Sector Policy;

- Represent Nagapattinam Regionally on postal matters;

- Issue guidelines on postage stamps including definitive, commemorative, special issues and any other Stamp collecting items;

- Undertake regular inspections of the performance of all licensed operators;

- Weed-out illegal operators from the sector.

\section{Conclusion}

The Postal and Courier Sector have a prime opportunity to become a trusted partner in the region. There is considerable good will for the sector. Postal organizations have captured the interest of the Government because of efforts to reform operations and widen its scope.

Today postal department has to equip itself by improving its service and saving schemes to satisfy the customers. In the light of changing environment, it has constantly upgrade its knowledge of the internal and external environment to understand the customer relationship properly. Saving is important for human life as savings gives life and security. One of the main motives of the Department of Post is to uplift the savings of the people. Savings not only help the people, but also help for the economic development.

The researcher hence strongly believes that the post offices is the only public organization which is more intimately bonded with human relations than any other government department. It is universally recognized as a facilitator of communications. Though there are many saving options available, as a public organization, the Department of Post should try to give innovative saving schemes to the public. The researcher concludes that India Post is all set to become strong and stronger, spreading a joyful light to people everywhere. It is bound to overcome all the hurdles presented by the new environment in the electronic age. Its doors are thrown wide open with customer delight in mind. It goes on with a noble mission of uniting humankind world over.

$* * * * * * *$ 